\title{
Original DocumentsExtracts from The Bursar's Accounts, Preserved Among The Muniments of Winchester College
}

\section{W. H. Gunner}

To cite this article: W. H. Gunner (1851) Original DocumentsExtracts from The Bursar's Accounts, Preserved Among The Muniments of Winchester College, Archaeological Journal, 8:1, 79-87, DOI: $10.1080 / 00665983.1851 .10850833$

To link to this article: http://dx.doi.org/10.1080/00665983.1851.10850833

Published online: 10 Jul 2014.

Submit your article to this journal $\pi$ 


\section{Gríginal 軔ocuments.}

\section{EXTRACTS FROM THE BURSAR'S ACCOUNTS, PRESERVED AMONG THE MUNIMENTS OF WINCHESTER COLLEGE.}

THE rolls of accounts of the household expenditure of the nobles, and of Monastic and other institutions of the middle ages, which have come down to us, contain most valuable information relating to the mode of the daily life, and habits, and customs of our forefathers. Uninteresting and forbidding as they may at first appear to be, the Archaeologist, who wishes to become acquainted with the inner and more private life of the times which fall within the scope of his inquiry, should by no means neglect them ; and if undeterred by their forbidding aspect, he will have patience to proceed, he may find much to interest him and to reward his labour. My attention was first drawn to the very valuable series of Bursarial Rolls, preserved among the Muniments of Winchester College, by the Rev. Dr. Rock, who requested me to verify a quotation made from one of them by the learned Thomas Warton, in his "History of English Poetry." In searching for the extract in question, I jotted down in my note book many things which excited my interest; and was led on to continue my investigation, which has now extended from the seventeenth of Richard II., to the eleventh of Henry VI., during which period the series, with a few exceptions, is tolerably perfect.

The expenditure is arranged under the heads of the cost of the various departments, such as the Chapel, Hall, Library, Kitchen, Stable, Legal Proceedings, Gifts, Forinsec Expenses, \&c., and the cost of the commons of all the members of the house arranged in weeks.

The following extracts are taken incidentally from various rolls, and selected as touching upon subjects of more general interest. The first extract which I shall cite, is the one quoted by Thomas Warton, and is taken from the earliest of these rolls, which is thus endorsed,-Collegium beatæ Mariæ prope Winton, anno viII ${ }^{\text {vo }}$ ab inceptione operis. Computus primus post ingressum in idem Collegium, anno reg. Ric. $2^{\text {ndi }}$ post conquestum $\mathrm{XvII}^{\circ}$. It is interesting, as showing that the practice of writing on waxen tablets was not wholly disused even at a period comparatively late.

Et in i. tabula ceranda cum viridi cera pro intitulatione capellanorum et clericorum capellæ, ad missas et alia psallenda viii ${ }^{\mathrm{d}}$.

The following extracts are selected, as showing the cost of making books for the services of the chapel :-

19, 20 Ric. II.

Item computat pro quatuor doseyn septem pellibus de velym emptis pro uno graduali inde facto, quod incipit secundo folio, "et dicatur," continenti septem et viginti quaternos cum custodiis,' pretium doseyn de velym, $v^{s}$, pret. pellis, $v^{d}$

Et in scriptura ejusdem gradualis

$E t$ in notatione ejusdem

$\mathbf{x x i i}{ }^{8} \mathrm{xi}^{\mathrm{d}}$

$x$ vii ${ }^{s}$

xiii s iiii $^{\mathrm{d}}$
1 The fly-leaves, probably, or as might now be said, the guards. Custodia is used in this sense in a description of Books in
Visit. of Treas. St. Paul's, London, in 1295. (Dugdale.) 
Et in illuminatione et ligatione ejusdem

Item in II dozeyn, II pellibus de velym emptis pro i. collectario, quod incipit secundo folio, "Vicio," continenti xIII quaternos, pretium doseyn, iiii s, pretium pellis, iiii d .

Et in scriptura notatione, illuminatione et ligatione ejusdem

Item in XI dozeyn, III pellibus empt. pro legenda integra, quæ incipit sec. folio, "quia dixerunt," continenti xxxIII quaternos, pretium dozeyn, fiii s vid, pret' pellis. iiii d, ob. .

Et in scriptura ejusdem legendæ

Et in illum. et ligat. ejusdem

Item in sex dozeyn de velym emptis pro factura sex processionalium, quorum quodlibet continet $\mathrm{XV}$ quaternos, pretium dozeyn, iiii ${ }^{\mathrm{s}} \mathrm{vi}^{\mathrm{d}}$

Etin scriptura notatione, illuminatione, et ligatione eorumdem

Item in vII pellibus cervinis emptis pro libris prædictis cooperiendis

The following are specimens of the cost of other books for the use of the library and school.

\section{0, 11 Henry IV.}

In I libro grammaticali voc' "Papiæ" empto hoc anno de Magistro Joanni Melton ${ }^{3}$ in festo Se'e Katerinæe et A.D. MCCCCIx, xxxiii s iii ${ }^{\mathrm{d}}$

In dicto libro et I altero libro voc. " Hugonis" " pelle vitulina cooperiendis cum clapsula ad idem, $x^{d}$.

\section{Henry V.}

In soluto cuidam scriptori de Abhatia Sc'e Marie pro scriptura II quaternorum de libro Moralium abbreviato per Magistrum Joannem Elmer : ${ }^{5}$ capienti pro scriptura cujuslibet quaterni, ii s iii ${ }^{d}$.

In soluto eidem scriptori pro scriptura $x v i$ quaternorum et dimidii de libro prædicto Moralium et al' : qui capit pro quolibet quaterno, ii s ; simul cum $\mathrm{v}^{\mathrm{s}}$, pro $\mathrm{Ix}$ quaternis pergameni ab eodem emptis pro dictis libris, xxxviii s.

The date of the roll, from which the following extracts on the same subject are taken, is obliterated; but it belongs to the reign of Henry V.

In soluto dno Joanni Smyth pro duobus partibus de Lira ${ }^{6}$ abbreviatis per magistrum Joh. Elmer, ix ${ }^{1}$ vi $^{\text {s }}$ viii d. In una alia parte de Lira super quatuor evangelistas non abbreviata : emp. liiis iiii d. In uno libro decre-

2 This was probably the "Elementarium doctringe, sive vocabularium" of Papias the Grammarian, a native of Lombardy, called Vocabulista, from this work. He flourished about the middle of the 11th century.

${ }^{3}$ John Melton was the first Head Master of the School.

4 Probably a work of Hugo de Saneto Victore.

5 John Elmer was deputed, together with Dr. Nicholas Wykeham, A.D. 1402-3, to administer the affairs of the See of Winchester, which the age and infirmities of Wm. of Wykeham rendered him unable to attend to. He was also one of the executors of the Bishop's Will.

6 Nicholas de Lira, born at Lire, in the diocese of Evreux, of Jewish parents. On his conversion to Christianity, he assumed the habit of the Minorites in the convent of Verneuil. He was afterwards appointed a Professor of Theology in the University of Paris, where he delivered lectures on the Holy Scriptures, in the Franciscan convent, and afterwards published two commentaries, one on the text of Seripture; the other, practical. He was selected as one of the executors of Joan of France. He died A. D. J 340. Cave. Hist. Lit. 


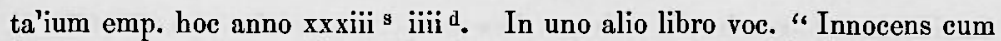
duobus doctoribus," xiii s iiii d. In uno libro vocato "Magister Sententiarum," cum I quaterno continenti "Speculum penitentiæ," 7 xxiii s iiii d. In uno alio libro voc. "Soliloquium ;" vii ${ }^{\mathrm{s}}$. In uno libro ${ }^{9}$ de sex verbis Dni in cruce empt. vi ${ }^{\mathrm{s}} \mathrm{x}^{\mathrm{d}}$. In uno missali empt. apud Seinte Cros Juxta Wynton, $x x^{s}$. In uno manuali empt. quod liberatur ad ecclesiam de Titteley, $\mathrm{xi}^{\mathrm{s}}$ iiii $^{\mathrm{d}}$. In soluto pro scriptura XIII quaternorum de libris moralium abbreviatis per magistrum Johannem Elmer, xxvis. In soluto pro scriptura vII quaternorum et dimidii unius libri vocati, "Angelicus super Joannem" abbreviati per dictum Mag. Joh. Elmer una cum $\mathbf{x v}$ pellibus vitulinis empt. ab eodem, xvii s vii ${ }^{d} \mathrm{ob}$. In soluto pro notatione cujusdam manualis simul cum crucifixo in eodem faciendo, iii $\mathrm{s}$.

The next extracts which I shall give, relate to the costs incurred in providing materials for, and in the sculpture, painting, \&c., of a set of images for the rood loft of the chapel, in the 3 \& 4 Henry IV.

In soluto pro sculptura imaginum Crucifixi B. Mariæ et Sci Joannis una cum meremio empt. pro eisdem London,' quie stare debent in Capella, lxviii s iiiid.

Et pro factura patibuli Crucifixi, et pro meremio empt. pro eodem, xxii s.

Et pro pictura imaginum et patibuli sive crucis prædictæ, iiii ${ }^{1} x^{s}$ iii d.

Et pro portatione prædictarum imaginum et crucis ad manus artificum ad diversa loca London,' una cum expensis unius hominis-pro dictis operibus, vii s.

Et pro una domo conducta ad conservandas dictas imagines post depictionem, xii ${ }^{\mathrm{d}}$.

Et in tribus cases factis de tabulis ad imponendas dictas imagines cum clavis pro eisdem empt. et pro panno lineo pro eisdem involvendis pro eorum (sic) indempnitate tempore cariagii, xiiii $^{\mathrm{s}}$ ii ${ }^{\mathrm{d}}$.

Et pro cariagio predictarum imaginum et crucis a London' usque Wynton, xvi s iiiid.

Et in soluto Will'mo Ikenham pro factura trium bases ligneorum pro dicta cruce et prædictis imaginibus ponendis, una cum positione earundem super dictas bases, $\mathrm{xx}^{\mathrm{s}}$.

I shall confine the extracts from the Custus Capellæ to one or two items relating to a few matters required for the services; after noticing one which satisfactorily fixes the date of a portion of the buildings of the College, which, on very insufficient grounds, have sometimes been assigned to a later period, and other benefactors than the sole and munificent Founder of the two St. Mary Winton Colleges. It runs thus :-

18, 19 Ric. II.

In expensis suffraganei dñi Episcopi Wynton', existentis in Collegio cum

7 This may have been a tract written under this title by William de Monte, or Montibus, a native of Leicester, Professor of Theology at Oxford, and Canon and Chancellor of Lincoln, where he died, and was buried in the cathedral, Reg. Joh. He seems to have been a voluminous writer. A work of his called "Summa brevis," and another called "Summa numerorum," in twelve books in MS., VOL. VIII. were once in the Library of New College. Pitseus, p. 285.

$\&$ Two treatises under these titles, once assigned to St. Augustine, were rejected as spurious by the Benedictine editors, and placed by them in the Appendix of the 6th Vol. of his Works.

9 Arnold Abbat of Bonneval, diocese of Chartres, wrote a tract under this title. Flourished A.D. 1162.-Cave. Hist. Lit. 
familia et equis suis per quinque dies tempore consecrationis Capellæ et Cimiterii et Claustri Collegii Winton, die Sabbati in festo Se'i Kenelmi (July 17, 1396); una cum expensis aliorum extraneorum supervenientium per vices, et pro die principali confectionis specialiter invitatis, una cum donis datis diversis de familia prædicti suffraganei, $\operatorname{xlix}^{\mathrm{s}} \mathrm{v}^{\mathrm{d}} \mathrm{ob}$.

The suffragan, to whom William of Wykeham gave his commission to consecrate the Chapel, Cloister, and Cemetery of his newly finished College at Winchester, was Simon, bishop of Aghadoe, in Ireland. The late Bishop Milner, Vicar-Apostolical, in his History of Winchester, as also the anonymous author of an older history, have supposed that the Cloisters of Winchester College were not the work of Wykeham, and have assigned them to Fromond, the founder of the Chantry Chapel, which stands within them : they were probably misled by the terms of the commission issued to the bishop of Aghadoe, a copy of which is preserved in Wykeham's Register, and the original itself in the muniment room of the College. In this no mention is made of the Cloisters, and the Cemetery is spoken of as "locus in Cimiterium destinatus." They inferred from this that the Cloisters had not yet been built. The extract given above, with many others in these rolls, relating to repairs done to the Cloisters anterior to the time of Fromond's building, prove beyond a doubt that the Cloisters are the work of Wykeham himself.

The following charge occurs in the roll of 12,13 Henry IV.

In rewardo dato Joanni Berton pro scriptura historiæ Corporis Christi, et Sce' Anne, et pro duplicatione eorumdem, una cum ympnis, et aliis correctionibus factis per eundem in diversis libris, iii $s$ iii $\mathrm{d}$.

In the $2 \& 3$ Henry V., we meet with the cost of some beautiful frontels for the high, and the two inferior altars of the Chapel.

In soluto Joanni Halle Mercier, London' pro duobus frontellis de albo fustian pro summo altari' operatis in medio imagine Crucifixi, Marie et Joannis, et pulverizatis cum rosis rubris; ac quatuor frontellis de eodem panno simili modo operatis et pulverizatis, pro altaribus inferioribus, $1 \mathrm{xv} s$.

In the 4 Henry VI., the following charges occur under this head.

In cordulis et splintris emp. pro sepulchro Dñico, vi d.

In solut. pro factura quatuor amiciarum, cum iiii ${ }^{d}$ datis clerico Prioris Sci' Swithini temp. benedictionis earumdem, vi d.

In solut. pro I cressant de argento deaurato pro eucharistia supportanda in pixide de crystal, habente in pondere, xiii ${ }^{\mathrm{d}}$, cum viii ${ }^{d}$ pro factura, xxii ${ }^{\mathrm{d}}$. In solut. Thomæ Smyth pro xXIII pynnes ferreis pro cruce triangulari ordinat. pro candelis infigendis tribus noctibus ante Pascha, xii ${ }^{\mathrm{d}}$.

The charges under the head of the Cost of the Hall contain nothing that need be cited, except the following, which occurs twice in the 8 and 9 of Henry IV., and 3 of Henry VI.

In viridibus candelis et ramis arborum empt' erga festum Nat' Sc'i Joannis Baptistæ xiiid.

I have not met with anything that throws light upon the practice of burning green candles on this festival.

Amongst the charges, which occur under the head of Gifts, are many items, constantly recurring, for presents given to the officers of justice, and administrators of the law, in order to secure their friendship and goodwill in matters affecting the interests of the College. The recipients of these gifts are generally the sheriff, or his deputy, or the jury ; but sometimes offerings are made to persons far higher than they. The Admiral of 
England, the King's justices, and even, in one instance, the Archbishop of Canterbury himself, deigned to accept gifts offered to secure their good offices. It may be observed that these gifts are certainly not mere fees of office, for they are generally not sums of money, but gloves, wine, fruit, fish, or other delicacies ; and they are always entered as given to such and such a person " ut favorabilis esset," or " pro amicitia sua liabenda." The Admiral accepted vi ${ }^{s}$ viii ${ }^{d}$ as his douceur. The undersheriff of Berkshire on one occasion seems to have been very hard to buy. In the 6 and 7 Henry IV., in a matter concerning the Manor of Shawe, then the property of the College, he received first a pair of gloves, price viii d, " ut favorabilis esset;" a little after, vi s viii d was paid him, " pro amicitia sua labenda ;" again he received the same sum, "ut favorabilior esset;" then another pair of gloves and wine, which cost xii " " pro amicitia sua ;" and yet again vi $^{\text {s }}$ viii ${ }^{d}$ for the same object. The favour and friendship of this officer had to be purchased at the cost of a mark and a half in money, a large sum for those days. But the friendship and favour of the Archbishop of Canterbury was rated at a much higher value. I will quote the item, which is as follows:-

In quodam dono dat. Dno Archiepiscopo Cantuariensi pro bona adjuvatione sua habenda de exoneratione decimæ concessæ Dño Regi per clerum in convocatione celebrata London' dec' oct' die Nov, una cum $x$ s dat' cuidam clerico dic' Dni Archiepiscopi pro sollicitatione sua habenda ad predictum Dńm Archiep'm, cx s. (4 Henry V.)

This was Archbishop Chichele, himself a son of Wykeham, and an imitator of his munificent example. We can scarcely suppose that it was necessary to secure by a bribe the friendship and influence of one who had been himself a recipient of Wykeham's bounty, in a matter affecting the interests of one of his colleges. We must rather believe that it would have been thought discourteous to refuse, what was offered as a compliment. Nor, indeed, ought we to judge of these gifts in general, according to our modern notions of what is becoming to the character of public officers. It is well, indeed, that such practices have been done away; but it is probable that, when they were in vogue, they did not much interfere with the due course of justice. Gifts, no doubt, were offered by both sides in a suit, and were considered rather as matters of courtesy and compliment, than as likely to bias the minds of public officers; though, at the same time, it would probably have been very impolitic in either party to withhold them.

The gifts charged under the various items of this head are of a very miscellaneous character. There are frequent payments made to minstrels, dancers, and players, for entertaining (solaciantibus) the members of the college on some of the great festivals of the Church. Sometimes these persons are described as the minstrels, or players of the city of Winchester, and other places; sometimes they appear as attached to the suite of some great person visiting Winchester, for instance, 4 Henry V., occurs the following :-

In dato IIII ministrallis Dn̈i Humfredi ducis Gloucestrie ven' ad Collegium xiiiito die Feb., iii s iiii $^{\mathrm{d}}$.

The minstrels of the Lord Cardinal Beaufort, and of his sister, the Countess of Westmoreland, were hired in the same manner. The feast of the holy Innocents was usually enlivened in this way; on which occasion the boys of the school took part in the entertainment, under their Boy Bishop. As an instance of this, the following item occurs, in the time of Henry V.:-

In dato diversis lominibus de Ropley, in festo Sc'or' Innocentium tripidiantibus, et cantantibus cantilenas in Aula coram Episcopo Scolarium xx ${ }^{\star}$. 
The Bishop of Winchester was a frequent recipient of presents from the College. Possibly the countenance and protection of so powerful a prelate as Henry Beaufort was of great service to the foundation of his munificent predecessor ; and he seems to have felt an extraordinary degree of interest in its welfare, and to have befriended and supported it with all his influence. It is clear that he maintained the most friendly intercourse with the College. which was acknowledged by liberal presents. Charges very frequently occur for the purchase of dainties for the Bishop's table while he sojourned at Wolvesey. Fish, salted and fresh, meat, fowls, fruits, and preserves, all procured at a great expense by means of special messengers from the markets which were in best repute for any particular article $;^{1}$ while the most sedulous attention seems to have been given to ascertain what delicacies would be most acceptable to the Bishop. Occasionally his cook, John Rymayn, is consulted on this point, and he has a fee for his advice. On one occasion the Bishop is presented with hunting gear, the cost of which is found in the undated roll of $t$. Henry V. The items are as follows:-

In XII arcubus empt. apud London. mense Maio pro dno Epo' Wynton, et familia sua, ad dandum inter eosdem temp. venationis in diversis parcis suis comitatus Suthamptoniæ, xxii s viii ${ }^{d}$. In vI duodenis sagittarum pennis pavonum et aliarum volucrum pennatis, emptis eodem tempore pro dno Epo', xviii s ii d. In vi duodenis capitum barbillatorum, emptorum pro dictis sagittis eodem tempore, viii ${ }^{\mathrm{s}}$ viii $^{\mathrm{d}}$. In uno Wardebras argenteo et deaurato, pendente duas uncias, unum quartron : una cum factura et deauratione ejusdem, $\mathrm{xi}^{\mathrm{s}}$ vid. In uno lase serico viridis coloris cum uno knapp de goldwyr, iiii d. In xII huyles emptis ibidem ad dandum inter clericos suos ibidem eodem tempore, viii s vid. In cistis et coffyns empt. pro dictis donis emptis London. imponendis et cariandis de London' usque Wynton, xxiii d.

Mention occurs elsewhere of arrows feathered with peacock's plumage, probably esteemed as more choice than common feathers. John Palman, in 1436 , bequeaths to his son " $\mathrm{j}$. arcum optimum cum $\mathrm{j}$. sheef arrowys de pecok." Wills and Invent. Surtees Soc. vol. 1, p. 87. Amongst the stores of Bp. Waynflete, at Faruham Castle, 1471, were "sagittæ magnæ barbatæ cum pennis pavonum." Lydgate mentions such arrows, Chron. of Troy, B. iii., c. 22 . The green silk lace, with a knop of gold wire, was possibly the " arrow girdle," by which arrows were carried at the left side. The Bishop's silver-gilt "wardebras," the gardebras, or bracer. to protect the left arm, was of singularly costly material. Its form is well shown by a drawing in the Louterell Psalter, copied in Vetusta Monum. vol. vi., pl. 24. These items recall Chaucer's description of the Squire's "Yeman :"-

"A shefe of peacock arwes bright and kene,
Under his belt he bare ful thriftily;
Upon his arme he bare a gaie bracer."
Prologue, Canterbury Tales, v. 104.

The prelate's clerici received some kind of cap as a gratification on this occasion. The term "huyre" is of uncommon occurrence. A Petition of the Commons, 22 Edw. IV., 1482, may be found in the Rolls of

I Ex.gr. salted lampreys, and salmon, were procured from Gloucester; perch and tench from Oxford; crabs from
Salisbury. Horses for the use of the College were purchased at the fair of Amesbury. 
Parliament, respecting the deterioration of the quality of "Huers, bonettes and cappes," alleged to have arisen from the use of fulling mills. ${ }^{2}$ A cap, or a livery hood, it will be remembered, was a customary present at the period, a little gratuity or annual retaining gift, as appears by the various Statutes against Maintenance.

Proofs are found in these rolls of the excitement, in which the country bordering on the sea coast of the south of England was kept by alarms of attacks from the French, during the wars of Henry V. The College was often obliged to incur the expense of sending men-at-arms to assist in the defence of the country, in their Manor of Hamble, now known as Hamblele-Rice, situate at the mouth of the Southampton Water. I may cite as an instance the following, which occurs in the 4th of Henry V.:-

In expensis dni Willelmi Hayne, Walteri Harley, Magistri Will'mi Grover, et aliorum de Collegio equitantium et peditantium ad Hamele in le Rys, et ibidem existentium per III dies pro defensione patriæ contra inimicos dńi Regis et regni sui et totius patriæ, una cum expensis Walteri Wallyngford et aliorum hominum secum peditantium ad Hamele prædictam pro simili causa, alia vice, et ultra expensas factas et solutas per Rob. Tichfeld firmarium ibidem, $x^{s}$ ix $\mathrm{d}$ ob. In cordulis et capitibus sagittarum empt. eod. temp. xii d. In dato III tenentibus de Roppele existent. apud Hamele prædicta, per unum diem et unam noctem post recessum hostium, pro majore securitate, \&c., xii d.

In the same year, the following liberal gratuity was given to the messenger, who brought to the College the tidings of the glorious victory of Agincourt. It will be observed that the terms, in which the entry is made, show the astonishment excited in England at the vast number of prisoners taken in that battle. It is as follows :-

In dato Joanni Coudray, filio Edw. Coudray, armigero Dni Epo' Wynton: deferenti novos rumores ad Collegium de ultra mare, de ducibus, comitibus, baronibus, militibus et aliis generosis de Francia captis per Dñm Regem nostrum nunc Angliæ, in quodam bello facto apud Agyncourt in Picardia in festo Sc'orum Crispini et Crispiniani, anno regni sui $3^{\text {tio }}$ et usque in Angliam postea cum dicto Dno Rege ductis, vi s viii d.

I shall conclude with a few extracts taken from a roll, headed, Expensa ultra onera consueta ab anno Regni Ric. $2^{\text {ndi, }}{ }^{\text {xviii }}{ }^{\circ}$ usque annum Regni Hen. 4 ti. 4 tum. The first item which I shall cite is the cost of a pair of Organs:-

In I pari organorum emptorum anno Reg. Hen. $4^{\text {to }}$ cum cariagio a London, vi lib iiis iiii d.

There is nothing in the cost of such organs to put them out of the reach of many a church, and religious house. Yet it would seem that such instruments in those days were either not to be met with everywhere; or that there must have been something peculiarly good in the College organs, for they were frequently borrowed by the Bishop of Winchester, and sent to him at his residence at Waltham, and even so far as Farnham and High Clere. In the $8 \mathrm{th}$ of Henry IV., the following charge occurs in the Bursar's roll :- In expensis vi scolarium deferentium organa de Collegio usque hospitium dni Epi' de Waltham, ix ${ }^{d}$ ob. In 2 nd of Hen. V. they had been sent to the Bishop at Farnham, as appears by the following :-

In expensis clericorum et puerorum Collegii cariantium organa Collegii

2 Parl. Rolls, vol. vi., p. 223. The Promptorium Parvulorum gives - "Huwyr (al. Hurwyr,) Tena." In the Bursar's Roll, 12,13 Hen. IV., above cited, with gloves and purses bought at London for presents, is the item-" In vi. huyres cappes empt', pro donis dandis, iiii s." 
de Farnham usque Collegium Wynton, ii ${ }^{\mathrm{s}}$ iiii ${ }^{\mathrm{d}}$. The following extract, from the undated roll of Henry V., shows us how they were carried, and protected during the carriage :-

In panno lineo empto pro organis Collegii cooperiendis cariandis usque Clere $\mathrm{xx}^{\mathrm{d}}$. In dicto panno incerando $\mathrm{xx}^{\mathrm{d}}{ }^{\mathrm{d}}$. In II baculis fraxineis pro eisdem organis portandis viii ${ }^{d}$.

The following extracts from this roll of extraordinary expenses would be of considerable value, if the churches, to which they refer, had not subsequently undergone, as I fear is the case with most of them, very considerable alterations, and in some cases total destruction. In order to explain how these charges occur among the expenses of Winchester College, I may observe that the Founder, when he transferred to his Colleges the rectories and manors, which he had purchased of certain foreign abbeys, with a view to their endowment, required of them that they should put the chancels of the churches into thorough repair, and even rebuild them if necessary. This was accordingly done at Harmondsworth, Isleworth, Heston, Hampton, and Twickenham, in Middlesex ; and at Hamble and Hound in Hampshire. The five first mentioned places ceased to be the property of the College in the time of Henry VIII., who took them in exchange for other properties, which had belonged to suppressed monasteries :-

In soluto pro operibus novi (sic) cancelli (sic) ecclesiæ de Harmondsworth factis annis prædictis, (scil. 20,21, Ric. II.) una cum vitriatione IIII fenestrarum, et cum expensis dedicationis ejusdem cancelli lxviii li iii s ob.

Item solut' pro operibus cancellarum (sic) novarum (sic) de Heston et Iselworth cum vitriatione IIII fenestrarum et dedicatione earumdem, præter $c^{s}$ receptos de Coffre dni, ut patet in computo de annis xxii ${ }^{\text {do }}$ et xxiii tio iiii ${ }^{\mathrm{xx}}$ xiiii ${ }^{\mathrm{li}}$.

Item solut' pro operibus murorum cancelli novi (sic) factis apud Hampton in Com' Middlesex' una cum expensis factis pro materia providenda ro cancello de Twickenham ut patet, \&c. (1, 2, Hen. IV.), lxvi i. iiii ${ }^{\text {s }}$ vii d.

Item in nova constructione tecti ejusdem cancelli de Hampton et vitriatione $\mathbf{v}$ fenestrarum ejusdem $(3,4$, Hen. IV.), xii li : xiii s: vi d.

Item in nova constructione cancelli de Twickenham præter vitriationem fenestrarum, quæ adhuc non est facta, ut patet, \&c., xxxii li : xiï ${ }^{\mathrm{a}}$ : vii ${ }^{\mathrm{d}}$.

Item solut' pro operibus factis in Ecclesia de Hamele, et in nova constructione tecti ecclesiæ ibidem, ut patet in computo de annis reg' Hen. $3^{\circ}$ et $4^{\circ}$ præter expensas novi columbarii ibidem facti, quod computatur inter opera dni, $x$ vii li vii s ${ }^{d}$.

The charges of the repairs of this church, with its dependent chapels of Hound, Bursledon, and Letley, hodie Netley, extend over several years, and are accounted for by the Bursar among the ordinary expenses. In 12 and 13 of Hen. IV., there is a charge of xiii s, paid to the suffragan of the Bishop of Winchester for the consecration of the altars of the chapel of Bursledon, and Letley ; and a similar charge in the undated roll of Henry V. for the consecration of altars at Hound and Bursledon.

In the same year the bell tower of the church of Hamble-le-Rice underwent very considerable repairs, if, indeed, it was not entirely rebuilt, the materials for which were provided at the following cost:-

In III duodenis de bordes, et tribus plankes emp' per Will ${ }^{m}$ Ikenham 
apud Allyngton pro eampanili de Hamele xiii s, cum cariagio. In soluto Waltero Leeche de Wathe pro batillagio xxv ponderum dolii de Greneston de Wathe prædicto usque caiam ${ }^{3}$ de Hamele pro campanili ibidem, continentium oxXXvIII pecia, que continent de pedibus cco pedes, pretium pedis quadrati ii ${ }^{\mathrm{d}}$, ultra $\mathrm{xxvi}^{\mathrm{s}}$ viii $^{\mathrm{d}}$ receptos per Will' Mason de Roberto Tichefeld anno proxime præterito, xliii s.

The bells for this tower had been provided before, in the 1st of Henry V., as appears by the following :-In denariis liberatis Ric' Brasier de Wykeham pro tribus novis campanis factis pro ecclesia de Hamele, ultra tres veteres campanas, ut in partem solut', $\mathrm{xl}^{\mathrm{s}}$.

W. H. GUNNER.

\section{ARMORY OF WINCHESTER COLLEGE.}

Inventory taken about the year 1455 .

The following document may not inappropriately be appended to the interesting extracts for which the Society is indebted to Mr. Gunner. It is found in a Register amongst the College Muniments, containing lists of the Wardens, inventories of books, sacred ornaments, furniture, \&e. These were taken a few years after the decease of Robert Thurnberne, Warden from 1413 to 1450 . The following list occurs after household effects :-

\section{ARMARIA.}

Item, xlvj. de Basnettes et Palettes cum xxxiij. Ventall'. Item, ij. par' de Plates integ' coopert' cum blod' velvett', quorum j. cum Frenge de serico. Item, vij. Brestplates cum iiij. Pusiones. Item, viij. par' Rerebrases et ij. pro j. arm'. Item, viij. vambrases, cum iiij. par' de leg harneys et $j$. leg' cum Cusshu. Item, ij. par' de Sabaturez cum vj. par' cirothecarum. Item, xv. lorice, cum xiij. Pollaxes, unde xij. de una et eadem secta. Item, xij. archus (sic) novi. Item, iij. shefes sagittarum. Item, j. Gesarme, et $\mathrm{j}$. Barelle pro loricis purgandis.

It would be curious to ascertain what had at any period been the number of men for whom equipment was kept in the armory. We find a disproportionate number of head-pieces, not fewer than forty-six, and a slender supply of body-armour, with few weapons; a dozen new bows had been provided, with a modicum of arrows. It is clear that there was slight fear of hostile aggressions at that time.

There occur here some terms of military costume, which will be interesting to some of our readers. We find Palettes, not, as Sir Samuel Meyrick somewhat hastily surmised, round plates for the shoulder.joint, like a painter's palette, but head-pieces ; the pelluris, galea ex coreo et pelle, a defence, no doubt, of cuir bouilli. There were pusiones, or Pisans, not made at Pisa, but defences, as Mr. Hudson Turner well observes, for the pis, or breast. For the thighs of the collegiate guard there was small protection, the harness for one leg only having a quisshew, or cuissart. Hauberks there were fifteen, with a barrel in which they were cleansed from rust by rolling, the customary expedient, of which mention is made in other documents.

A. W.

${ }^{3}$ Kaia, or Caia, Sax. creg, a quay (Spelman). Hamble is situate near the mouth of a small æstuary, on the N. side of the Southampton Water. 